Joel Herness, MD; Jennifer Svarverud, DO; Debra Koenigsberger, MD; Kattie Hoy, MD Mike O'Callaghan Military Medical Center Family Medicine Residency Program, Nellis AFB, NV

ㅊoelherness@gmail.com

The authors reported no potential conflict of interest relevant to this article

doi: $10.12788 / j$ fp.0288
GRADE DEFINITIONS

For an explanation of USPSTF grade definitions, see www. uspreventiveservices taskforce.org/uspstf/ about-uspstf/methods and-processes/gradedefinitions

\title{
Vitamin supplementation in healthy patients: What does the evidence support?
}

\author{
This review, with handy tables, summarizes which \\ vitamins offer proven benefits-and which don't.
}

$\mathrm{S}$ ince their discovery in the early 1900s as the treatment for life-threatening deficiency syndromes, vitamins have been touted as panaceas for numerous ailments. While observational data have suggested potential correlations between vitamin status and every imaginable disease, randomized controlled trials (RCTs) have generally failed to find benefits from supplementation. Despite this lack of proven efficacy, more than half of older adults reported taking vitamins regularly. ${ }^{1}$

While most clinicians consider vitamins to be, at worst, expensive placebos, the potential for harm and dangerous interactions exists. Unlike pharmaceuticals, vitamins are generally unregulated, and the true content of many dietary supplements is often difficult to elucidate. Understanding the physiologic role, foundational evidence, and specific indications for the various vitamins is key to providing the best recommendations to patients.

Vitamins are essential organic nutrients, required in small quantities for normal metabolism. Since they are not synthesized endogenously, they must be ingested via food intake. In the developed world, vitamin deficiency syndromes are rare, thanks to sufficiently balanced diets and availability of fortified foods. The focus of this article will be on vitamin supplementation in healthy patients with well-balanced diets. TABLE W1 ${ }^{2}$ (available at mdedge.com/familymedicine) lists the 13 recognized vitamins, their recom- mended dietary allowances, and any known toxicity risks. TABLE $2^{2}$ outlines elements of the history to consider when evaluating for deficiency. A summary of the most clinically significant evidence for vitamin supplementation follows; a more comprehensive review can be found in TABLE 3..$^{3-96}$

\section{B COMPLEX VITAMINS}

\section{Vitamin B1}

I Vitamers: Thiamine (thiamin)

IPhysiologic role: Critical in carbohydrate and amino-acid catabolism and energy metabolism

I Dietary sources: Whole grains, meat, fish, fortified cereals, and breads

Thiamine serves as an essential cofactor in energy metabolism. ${ }^{2}$ Thiamine deficiency is responsible for beriberi syndrome (rare in the developed world) and Wernicke-Korsakoff syndrome, the latter of which is a relatively common complication of chronic alcohol dependence. Although thiamine's administration in these conditions can be curative, evidence is lacking to support its use preventively in patients with alcoholism. ${ }^{3}$ Thiamine has additionally been theorized to play a role in cardiac and cognitive function, but RCT data has not shown consistent patient-oriented benefits. $^{4,5}$

THE TAKEAWAY: Given the lack of evidence, supplementation in the general population is not recommended. 


\section{Vitamin B2}

Vitamers: Riboflavin

Physiologic role: Essential component of cellular function and growth, energy production, and metabolism of fats and drugs

Dietary sources: Eggs, organ meats, lean meats, milk, green vegetables, fortified cereals and grains

Riboflavin is essential to energy production, cellular growth, and metabolism. ${ }^{2}$

THE TAKEAWAY: Its use as migraine prophylaxis has limited data, ${ }^{97}$ but there is otherwise no evidence to support health benefits of riboflavin supplementation.

\section{Vitamin B3}

Vitamers: Nicotinic acid (niacin); nicotinamide (niacinamide); nicotinamide riboside - Physiologic role: Converted to nicotinamide adenine dinucleotide (NAD), which is widely required in most cellular metabolic redox processes. Crucial to the synthesis and metabolism of carbohydrates, fatty acids, and proteins

Dietary sources: Poultry, beef, fish, nuts, legumes, grains. (Tryptophan can also be converted to NAD.)

Niacin is readily converted to NAD, an essential coenzyme for multiple catalytic processes in the body. While niacin at doses more than 100 times the recommended dietary allowance (RDA; 1-3 g/d) has been extensively studied for its role in dyslipidemias, ${ }^{2}$ pharmacologic dosing is beyond the scope of this article.

THE TAKEAWAY: There is no evidence supporting a clinical benefit from niacin supplementation.

\section{Vitamin B5}

Vitamers: Pantothenic acid; pantethine I Physiologic role: Required for synthesis of coenzyme A (CoA) and acyl carrier protein, both essential in fatty acid and other anabolic/catabolic processes

- Dietary sources: Almost all plant/animalbased foods. Richest sources include beef, chicken, organ meats, whole grains, and some vegetables

Pantothenic acid is essential to multiple metabolic processes and readily available in
TABLE $2^{2}$

\section{Relevant history in the evaluation}

\section{of potential vitamin deficiency}

\begin{tabular}{|c|c|}
\hline Historical element & Applicable vitamin(s) \\
\hline \multicolumn{2}{|l|}{ Screening questions } \\
\hline $\begin{array}{l}\text { Are there any food groups that you avoid in their } \\
\text { entirety? }\end{array}$ & Multiple \\
\hline $\begin{array}{l}\text { How often do you eat animal products such as meat } \\
\text { or dairy? }\end{array}$ & $\begin{array}{l}\text { Vitamin } B 12, \\
\text { riboflavin }\end{array}$ \\
\hline \multicolumn{2}{|l|}{ Chronic conditions } \\
\hline Chronic kidney disease & Vitamin D \\
\hline $\begin{array}{l}\text { Conditions causing increased utilization: hemolysis, } \\
\text { sickle cell anemia, thalassemia, neurologic disorders, } \\
\text { exfoliative dermatitis, transplant, chemotherapy }\end{array}$ & Multiple \\
\hline Gastrointestinal/malabsorptive conditions & Multiple \\
\hline Genetic conditions & Multiple \\
\hline History of gastric bypass & Multiple \\
\hline Lactation & Multiple \\
\hline $\begin{array}{l}\text { Mental health conditions that limit diet } \\
\text { (eg, anorexia, dementia, autism) }\end{array}$ & Multiple \\
\hline Pregnancy & Folate \\
\hline Osteoporosis & Vitamin D \\
\hline \multicolumn{2}{|l|}{ Medications } \\
\hline Antibiotics (chronic use) & Vitamin K \\
\hline Antiepileptics & Vitamin B6, folate \\
\hline Antiretrovirals & Multiple \\
\hline $\mathrm{H} 2$ receptor antagonists & Vitamin B12 \\
\hline Isoniazid & Vitamin B6 \\
\hline Metformin & Vitamin B12 \\
\hline Methotrexate & Vitamin B6 \\
\hline Phenytoin & Vitamin B6 \\
\hline Proton pump inhibitors & Vitamin B12 \\
\hline Vitamin $\mathrm{K}$ antagonists & Vitamin K \\
\hline \multicolumn{2}{|l|}{ Social/diet history } \\
\hline Chronic alcohol use disorder & Multiple \\
\hline Extreme northern climate & Vitamin D \\
\hline Institutionalized/homebound & Multiple \\
\hline Ketogenic diet & B-vitamins \\
\hline Large amounts of raw egg whites & Biotin \\
\hline Poverty/homelessness & Multiple \\
\hline Vegetarian/vegan diet & $\begin{array}{l}\text { Vitamin } B 12, \\
\text { riboflavin }\end{array}$ \\
\hline
\end{tabular}

sufficient amounts in most foods. ${ }^{2}$ Although limited RCT data suggest pantethine may improve lipid measures, ${ }^{12,98,99}$ pantothenic acid itself does not seem to share this effect. 
TABLE 3

Vitamin supplementation: The evidence at a glance

\begin{tabular}{|c|c|c|c|}
\hline Vitamin & Disease/function & Evidence summary & Quality/type of evidence \\
\hline \multirow[t]{3}{*}{ B1 } & $\begin{array}{l}\text { Wernicke- } \\
\text { Korsakoff } \\
\text { syndrome }\end{array}$ & $\begin{array}{l}\text { No well-defined, evidence-based regimen for prevention or } \\
\text { treatment in people with alcoholism }\end{array}$ & Cochrane review of $\mathrm{RCTs}^{3}$ \\
\hline & $\mathrm{HF}$ & $\begin{array}{l}\text { Higher prevalence of deficiency among HF patients. } \\
\text { Supplementation may improve left ventricular ejection fraction; } \\
\text { no effect on mortality or patient-oriented outcomes }\end{array}$ & Systematic review of RCTs ${ }^{4}$ \\
\hline & $\begin{array}{l}\text { Alzheimer disease/ } \\
\text { dementia }\end{array}$ & Data too limited and low quality to draw conclusions & Cochrane review of RCTs ${ }^{5}$ \\
\hline \multirow[t]{2}{*}{ B2 } & Migraine & $\begin{array}{l}400 \mathrm{mg} / \mathrm{d} \text { reduced migraine frequency (NNT }=2.3 \text { for } 50 \% \\
\text { headache frequency reduction) in adults }\end{array}$ & 1 small $\mathrm{RCT}^{6}$ \\
\hline & Cancer & No consistent effect on cancer rates & Large cohort studies ${ }^{7-11}$ \\
\hline B3 & Cancer & No effect on cancer rates & Large cohort study ${ }^{8}$ \\
\hline B5 & $\begin{array}{l}\text { Cardiovascular } \\
\text { disease }\end{array}$ & $\begin{array}{l}\text { Pantethine (a form of vitamin B5) reduced LDL } 10 \%-20 \% \text {, } \\
\text { reduced triglycerides } 15 \%-30 \% \text {, and increased HDL } 6 \%-8 \% \text {. No } \\
\text { mortality or patient-oriented benefits }\end{array}$ & Systematic review of RCTs ${ }^{12}$ \\
\hline \multirow[t]{4}{*}{ B6 } & Stroke & $\begin{array}{l}\text { In conjunction with B9/B12, found to reduce stroke risk after } \\
5 \text { years of supplementation }(\mathrm{HR}=0.75 ; 95 \% \mathrm{Cl}, 0.59-0.97)\end{array}$ & 1 large $\mathrm{RCT}^{13}$ \\
\hline & Cancer & No consistent effect on cancer rates & $\begin{array}{l}\text { Multiple systematic reviews/ } \\
\text { meta-analyses }{ }^{14-16}\end{array}$ \\
\hline & Cognitive function & No effect on cognitive function & $\begin{array}{l}2 \text { systematic reviews/meta- } \\
\text { analyses }^{17,18}\end{array}$ \\
\hline & $\begin{array}{l}\text { Pregnancy- } \\
\text { associated nausea } \\
\text { and vomiting }\end{array}$ & $\begin{array}{l}\text { Recommended by the American College of Obstetricians and } \\
\text { Gynecologists; inconsistent data of benefit }\end{array}$ & $\begin{array}{l}\text { Meta-analysis/society } \\
\text { guideline }{ }^{19,20}\end{array}$ \\
\hline B7 & $\begin{array}{l}\text { Hair, nail, and skin } \\
\text { health }\end{array}$ & $\begin{array}{l}\text { Potential increased nail thickness. Case reports suggest } \\
\text { improved hair/skin health. }\end{array}$ & $\begin{array}{l}\text { Small, disease-oriented RCTs, } \\
\text { case reports }^{2}\end{array}$ \\
\hline \multirow[t]{5}{*}{ B9/B12 } & Preconception & $\begin{array}{l}\text { Folate recommended for women of childbearing age; found } \\
\text { to reduce risk of neural tube defects ( } \mathrm{RR}=0.31 ; 95 \% \mathrm{CI}, 0.17- \\
0.58) \text {. No consistent evidence of effect on other birth defects. }\end{array}$ & $\begin{array}{l}\text { Multiple systematic reviews/ } \\
\text { meta-analyses }{ }^{21-26}\end{array}$ \\
\hline & Cancer & $\begin{array}{l}\text { Inconsistent evidence on effects in cancer; some studies have } \\
\text { shown increased risk of colon cancer }\end{array}$ & $\begin{array}{l}\text { Multiple systematic reviews/ } \\
\text { meta-analyses }{ }^{27-29,30}\end{array}$ \\
\hline & $\begin{array}{l}\text { Cardiovascular } \\
\text { disease }\end{array}$ & No effect on cardiovascular events or mortality & $\begin{array}{l}\text { Multiple systematic reviews/ } \\
\text { meta-analyses }{ }^{31,32}\end{array}$ \\
\hline & Cognitive function & No consistent effect on cognitive function & $\begin{array}{l}\text { Multiple systematic reviews/ } \\
\text { meta-analyses }{ }^{18,33-35}\end{array}$ \\
\hline & Fractures & No evidence of decreased fracture risk & Large $\mathrm{RCTs}^{29,36}$ \\
\hline \multirow[t]{5}{*}{$\begin{array}{l}\text { Antioxidants } \\
(\mathrm{A}, \mathrm{E} \text {, and } \mathrm{C})\end{array}$} & AMD & $\begin{array}{l}\text { Small reduction in risk of advanced AMD when combined with } \\
\text { zinc }(\mathrm{OR}=0.72 ; 95 \% \mathrm{Cl}, 0.52-0.98)\end{array}$ & Large $\mathrm{RCT}^{37}$ \\
\hline & Cancer & $\begin{array}{l}\text { Observational data suggest slightly decreased colon cancer risk } \\
\text { associated with vitamin C and E. RCT data show no effect of } \\
\text { supplementation on cancer rates }\end{array}$ & $\begin{array}{l}\text { Large RCT, } 2 \text { pooled analyses of } \\
\text { cohort studies }^{38-40}\end{array}$ \\
\hline & $\begin{array}{l}\text { Cardiovascular } \\
\text { disease }\end{array}$ & No association with cardiovascular disease & Systematic review ${ }^{41}$ \\
\hline & Cataracts & No effect on age-related cataracts & Cochrane review of $\mathrm{RCTs}^{42}$ \\
\hline & Dementia & No effect on risk of Alzheimer disease & $\begin{array}{l}2 \text { systematic reviews/meta- } \\
\text { analyse }{ }^{35,43}\end{array}$ \\
\hline
\end{tabular}

THE TAKEAWAY: There is no data that supplementation of any form of vitamin B5 has any patient-oriented clinical benefits.
Vitamin B6

I Vitamers: Pyridoxine; pyridoxamine; pyridoxal I Physiologic role: Widely involved coen- 
TABLE 3

\section{Vitamin supplementation: The evidence at a glance (cont'd)}

\begin{tabular}{|c|c|c|c|}
\hline Vitamin & Disease/function & Evidence summary & Quality/type of evidence \\
\hline \multirow[t]{3}{*}{ A } & Bone density & $\begin{array}{l}\text { Retinol supplementation is associated with decreased bone } \\
\text { mineral density and in some studies, increased fracture risk }\end{array}$ & Systematic review ${ }^{44}$ \\
\hline & Cancer & $\begin{array}{l}\text { Beta-carotene associated with increased cancer mortality } \\
\text { among smokers and asbestos workers. No benefit on cancer } \\
\text { rates }\end{array}$ & Systematic review/meta-analysis ${ }^{41}$ \\
\hline & $\begin{array}{l}\text { Childhood } \\
\text { mortality }\end{array}$ & $\begin{array}{l}\text { Vitamin A supplementation in children ages } 4-60 \text { months } \\
\text { reduced mortality } 22 \%(95 \% \mathrm{Cl}, 10 \%-32 \%) \text { in nations at high } \\
\text { risk of vitamin A deficiency }\end{array}$ & Meta-analysis ${ }^{45}$ \\
\hline \multirow[t]{2}{*}{$\mathrm{E}$} & All-cause mortality & $\begin{array}{l}\text { Increased risk of all-cause mortality with supplementation of } \\
\geq 400 \mathrm{IU} / \mathrm{d} \text { of vitamin } \mathrm{E}(\mathrm{RR}=1.04 ; 95 \% \mathrm{Cl} 1.01-1.07)\end{array}$ & Meta-analysis ${ }^{46}$ \\
\hline & Cancer & $\begin{array}{l}\text { No benefit from supplementation on cancer rates. May } \\
\text { increase risk of prostate cancer }(\mathrm{HR}=1.17 ; 99 \% \mathrm{Cl}, 1.004-1.36)\end{array}$ & $\begin{array}{l}\text { Systematic review/meta-analysis, } \\
\text { RCT }^{11,47}\end{array}$ \\
\hline C & Common cold & $\begin{array}{l}\text { No significant reduction in incidence of cold. May reduce } \\
\text { duration by } 8 \%(95 \% \mathrm{Cl}, 3 \%-12 \%) \text {. May decrease incidence } \\
\text { in those subjected to brief, intense exercise and/or cold } \\
\text { temperatures }\end{array}$ & Cochrane review of RCTs ${ }^{48}$ \\
\hline \multirow[t]{16}{*}{ D } & \multirow[t]{2}{*}{$\begin{array}{l}\text { Fractures/bone } \\
\text { density }\end{array}$} & $\begin{array}{l}\text { Vitamin } D+\text { calcium supplementation may reduce hip fracture } \\
\text { risk in older adults }(R R=0.84 ; 95 \% C l, 0.74-0.96) \text {. No effect on } \\
\text { fracture risk with vitamin } D \text { alone }\end{array}$ & $\begin{array}{l}\text { Multiple systematic reviews/ } \\
\text { meta-analyses }\end{array}$ \\
\hline & & $\begin{array}{l}\text { No significant effect on bone mineral density in healthy } \\
\text { children }\end{array}$ & $\begin{array}{l}\text { Multiple systematic reviews/ } \\
\text { meta-analyses }{ }^{52,53}\end{array}$ \\
\hline & Falls & $\begin{array}{l}\text { No consistent effect on falls risk in community-dwelling elders. } \\
\text { Small reduction in rate of falls among institutionalized elders } \\
(\mathrm{RaR}, 0.72 ; 95 \% \mathrm{Cl}, 0.55-0.95)\end{array}$ & $\begin{array}{l}\text { Multiple systematic reviews/ } \\
\text { meta-analyses }\end{array}$ \\
\hline & All-cause mortality & No consistent effect on all-cause mortality & $\begin{array}{l}\text { Multiple systematic reviews/ } \\
\text { meta-analyses }{ }^{41,58-62}\end{array}$ \\
\hline & Cancer & No effect on cancer rates & $\begin{array}{l}\text { Multiple systematic reviews/ } \\
\text { meta-analyses }{ }^{41,62-66}\end{array}$ \\
\hline & \multirow[t]{2}{*}{$\begin{array}{l}\text { Cardiovascular } \\
\text { disease }\end{array}$} & No effect on cardiovascular disease outcomes & $\begin{array}{l}\text { Multiple systematic reviews/ } \\
\text { meta-analyses }{ }^{41,67-69}\end{array}$ \\
\hline & & No effect on hypertension & $\begin{array}{l}2 \text { systematic reviews/ } \\
\text { meta-analyses }{ }^{70,71}\end{array}$ \\
\hline & Dementia & No effect on cognitive function & $\begin{array}{l}2 \text { systematic reviews/meta- } \\
\text { analyses }{ }^{43,72}\end{array}$ \\
\hline & Chronic pain & No effect on chronic pain control or outcomes & $\begin{array}{l}\text { Multiple systematic reviews/ } \\
\text { meta-analyses }\end{array}$ \\
\hline & $\begin{array}{l}\text { Pregnancy adverse } \\
\text { outcomes }\end{array}$ & $\begin{array}{l}\text { Reduction in risk of pre-eclampsia (RR }=0.48 ; 95 \% \mathrm{Cl}, 0.30-0.79) \text {. } \\
\text { Reduction of risk of low birthweight infants ( } \mathrm{RR}=0.55 ; \mathrm{Cl}, 0.35- \\
0.87) \text {. No effect on rates of asthma or allergic disease in infants }\end{array}$ & $\begin{array}{l}\text { Multiple systematic reviews/ } \\
\text { meta-analyses }{ }^{76-82}\end{array}$ \\
\hline & $\begin{array}{l}\text { Upper respiratory } \\
\text { infections }\end{array}$ & $\begin{array}{l}\text { Reduction in risk of acute respiratory infection }(\mathrm{OR}=0.88 ; 95 \% \\
\mathrm{Cl}, 0.81-0.96)\end{array}$ & Systematic review/meta-analysis ${ }^{83}$ \\
\hline & Asthma & $\begin{array}{l}\text { Reduction in rate of exacerbation requiring corticosteroids } \\
\text { (alRR }=0.74 ; 95 \% \mathrm{Cl}, 0.56-0.97 \text { ) }\end{array}$ & Meta-analysis ${ }^{84}$ \\
\hline & Obesity & No effect on BMI & Systematic review/meta-analysis ${ }^{85}$ \\
\hline & Depression & No effect on depression scores or rates & $\begin{array}{l}2 \text { systematic reviews/meta- } \\
\text { analyses }^{86,87}\end{array}$ \\
\hline & Diabetes & $\begin{array}{l}\text { Low-quality/heterogenous data showing small reduction of } \\
\text { A } 1 \mathrm{C} \text { in those with type } 2 \text { diabetes }(-0.32 \% ; 95 \% \mathrm{Cl},-0.53 \text { to } \\
-0.10) \text {. No effect on rate of progression to diabetes }\end{array}$ & Systematic review and $\mathrm{RCT}^{88,89}$ \\
\hline & Liver disease & No effect on liver-related morbidity or quality of life & Systematic review/meta-analysis ${ }^{90}$ \\
\hline
\end{tabular}


TABLE 3

Vitamin supplementation: The evidence at a glance (cont'd)

\begin{tabular}{|c|c|c|c|}
\hline Vitamin & Disease/function & Evidence summary & Quality/type of evidence \\
\hline \multirow[t]{3}{*}{ Vitamin $\mathrm{K}$} & $\begin{array}{l}\text { Vitamin } \mathrm{K} \\
\text { deficiency bleeding } \\
\text { in newborns }\end{array}$ & $\begin{array}{l}\text { Intramuscular prophylaxis following delivery reduced risk of } \\
\text { moderate-to-severe bleeding }(\mathrm{RR}=0.19 ; \mathrm{Cl}, 0.08 \text { to } 0.46 ; \mathrm{NNT}= \\
74) \text { and reduced risk of bleeding after circumcision }(\mathrm{RR}=0.18 \text {; } \\
\mathrm{Cl}, 0.08 \text { to } 0.42 ; \mathrm{NNT}=9)\end{array}$ & $\begin{array}{l}\text { Systematic review of RCTs/ } \\
\text { observational studies }^{91}\end{array}$ \\
\hline & $\begin{array}{l}\text { Fractures/bone } \\
\text { density }\end{array}$ & $\begin{array}{l}\text { Potential benefit of supplementation on fracture risk (OR = } \\
0.72 ; 95 \% \mathrm{Cl}, 0.55-0.95) \text {. Inconsistent data for effect on bone } \\
\text { mineral density and vertebral fracture }\end{array}$ & $\begin{array}{l}2 \text { systematic reviews/meta- } \\
\text { analyses }^{92,93}\end{array}$ \\
\hline & Heart disease & $\begin{array}{l}\text { Observational data showing potential association between } \\
\text { dietary intake and cardiovascular disease risk. No RCT data on } \\
\text { supplementation }\end{array}$ & $\begin{array}{l}\text { Systematic review of } \\
\text { observational studies }^{94}\end{array}$ \\
\hline \multirow[t]{4}{*}{ Multivitamins } & All-cause mortality & No effect on all-cause mortality & $\begin{array}{l}\text { Systematic review of } 2 \text { large } \\
\text { RCTs }^{41}\end{array}$ \\
\hline & Cancer & $\begin{array}{l}\text { Borderline decrease in cancer rates in men }(\mathrm{RR}=0.93 ; 95 \% \mathrm{Cl} \text {, } \\
0.87-0.99) \text {. No effect on cancer rates among women or pooled } \\
\text { population }\end{array}$ & $\begin{array}{l}\text { Systematic review of } 2 \text { large } \\
\text { RCTs }{ }^{41}\end{array}$ \\
\hline & Cognitive function & No effect on cognitive function & Large $\mathrm{RCT}^{95}$ \\
\hline & Cataract/AMD & $\begin{array}{l}\text { Small reduction in cataract incidence }(\mathrm{HR}=0.91 ; 95 \% \mathrm{Cl}, 0.83- \\
0.99) \text {. No effect on AMD }\end{array}$ & Large RCT ${ }^{96}$ \\
\hline
\end{tabular}

aIRR, adjusted incidence rate ratio; AMD, age-related macular degeneration; BMI, body mass index; HDL, high-density lipoprotein; HF, heart failure; HR, hazard ratio; LDL, low-density lipoprotein; NNT, number needed to treat; OR, odds ratio; RaR, rate ratio; RCTs, randomized controlled trials; RR, relative risk.

zyme for cognitive development, neurotransmitter biosynthesis, homocysteine and glucose metabolism, immune function, and hemoglobin formation

Dietary sources: Fish, organ meats, potatoes/starchy vegetables, fruit (other than citrus), and fortified cereals

Pyridoxine is required for numerous enzymatic processes in the body, including biosynthesis of neurotransmitters and homeostasis of the amino acid homocysteine. ${ }^{2}$ While overt deficiency is rare, marginal insufficiency may become clinically apparent and has been associated with malabsorption, malignancies, pregnancy, heart disease, alcoholism, and use of drugs such as isoniazid, hydralazine, and levodopa/carbidopa. ${ }^{2}$ Vitamin B6 supplementation is known to decrease plasma homocysteine levels, a theorized intermediary for cardiovascular disease; however, studies have failed to consistently demonstrate patientoriented benefits. ${ }^{100-102}$ While observational data has suggested a correlation between vitamin B6 status and cancer risk, RCTs have not supported benefit from supplementation. ${ }^{14-16}$ Potential effects of vitamin B6 supplementation on cognitive function have also been studied without observed benefit. ${ }^{17,18}$
THE TAKEAWAY: Vitamin B6 is recommended as a potential treatment option for nausea in pregnancy. ${ }^{19}$ Otherwise, vitamin B6 is readily available in food, deficiency is rare, and no patient-oriented evidence supports supplementation in the general population.

\section{Vitamin B7}

\section{Vitamers: Biotin}

I Physiologic role: Cofactor in the metabolism of fatty acids, glucose, and amino acids. Also plays key role in histone modifications, gene regulation, and cell signaling

I Dietary sources: Widely available; most prevalent in organ meats, fish, meat, seeds, nuts, and vegetables (eg, sweet potatoes). Whole cooked eggs are a major source, but raw eggs contain avidin, which blocks absorption

Biotin serves a key role in metabolism, gene regulation, and cell signaling. ${ }^{2}$ Biotin is known to interfere with laboratory assaysincluding cardiac enzymes, thyroid studies, and hormone studies-at normal supplementation doses, resulting in both falsepositive and false-negative results. ${ }^{103}$

THE TAKEAWAY: No evidence supports the health benefits of biotin supplementation. 


\section{Vitamin B9}

Vitamers: Folates; folic acid

I Physiologic role: Functions as a coenzyme in the synthesis of DNA/RNA and metabolism of amino acids

I Dietary sources: Highest content in spinach, liver, asparagus, and brussels sprouts. Generally found in green leafy vegetables, fruits, nuts, beans, peas, seafood, eggs, dairy, meat, poultry, grains, and fortified cereals.

\section{Vitamin B12}

I Vitamers: Cyanocobalamin; hydroxocobalamin; methylcobalamin; adenosylcobalamin I Physiologic role: Required for red blood cell formation, neurologic function, and DNA synthesis

Dietary sources: Only in animal products: fish, poultry, meat, eggs, and milk/dairy products. Not present in plant foods. Fortified cereals, nutritional yeast are sources for vegans/vegetarians.

Given their linked physiologic roles, vitamins B9 and B12 are frequently studied together. Folate and cobalamins play key roles in nucleic acid synthesis and amino acid metabolism, with their most clinically significant role in hematopoiesis. Vitamin B12 is also essential to normal neurologic function. ${ }^{2}$

The US Preventive Services Task Force (USPSTF) recommends preconceptual folate supplementation of $0.4-0.8 \mathrm{mg} / \mathrm{d}$ in women of childbearing age to decrease the risk of fetal neural tube defects (grade A). ${ }^{21}$ This is supported by high-quality RCT evidence demonstrating a protective effect of daily folate supplementation in preventing neural tube defects. ${ }^{22}$ Folate supplementation's effect on other fetal birth defects has been investigated, but no benefit has been demonstrated. While observational studies have suggested an inverse relationship with folate status and fetal autism spectrum disorder, ${ }^{23-25}$ the RCT data is mixed. ${ }^{26}$

A potential role for folate in cancer prevention has been extensively investigated. An expert panel of the National Toxicology Program (NTP) concluded that folate supplementation does not reduce cancer risk in people with adequate baseline folate status based on high-quality meta-analysis data. ${ }^{27,104}$ Conversely, long-term follow-up from RCTs demonstrated an increased risk of colorectal adenomas and cancers, ${ }^{28,29}$ leading the NTP panel to conclude there is sufficient concern for adverse effects of folate on cancer growth to justify further research. ${ }^{104}$

Given folate and vitamin B12's homocysteine-reducing effects, it has been theorized that supplementation may protect from cardiovascular disease. However, despite extensive research, there remains no consistent patient-oriented outcomes data to support such a benefit. ${ }^{31,32,105}$

The evidence is mixed but generally has found no benefit of folate or vitamin B12 supplementation on cognitive function. ${ }^{18,33-35}$ Finally, RCT data has failed to demonstrate a reduction in fracture risk with supplementation. ${ }^{36,106}$

THE TAKEAWAY: High-quality RCT evidence demonstrates a protective effect of preconceptual daily folate supplementation in preventing neural tube defects. ${ }^{22}$ The USPSTF recommends preconceptual folate supplementation of $0.4-0.8 \mathrm{mg} / \mathrm{d}$ in women of childbearing age to decrease the risk of fetal neural tube defects.

\section{ANTIOXIDANTS}

In addition to their individual roles, vitamins $\mathrm{A}, \mathrm{E}$, and $\mathrm{C}$ are antioxidants, functioning to protect cells from oxidative damage by free radical species. ${ }^{2}$ Due to this shared role, these vitamins are commonly studied together. Antioxidants are hypothesized to protect from various diseases, including cancer, cardiovascular disease, dementia, autoimmune disorders, depression, cataracts, and age-related vision decline. . $^{2,37,107-112}$

Though observational studies have found a correlation of increased risk for disease with lower antioxidant serum levels, RCTs have not demonstrated a reduction in disease risk with supplementation and, in some cases, have found an increased risk of mortality. While several studies have found potential benefit of antioxidant use in reducing colon and breast cancer risk, ${ }^{38,113-115}$ vitamins $\mathrm{A}$ and $\mathrm{E}$ have been associated with increased risk of lung and prostate cancer, respectively. ${ }^{47,110}$ Cardiovascular disease and

\section{$>$ \\ While observational studies have found a correlation of increased risk for disease with lower antioxidant serum levels, RCTs have not demonstrated a reduction in disease risk with supplementation.}




\section{Vitamin C} supplementation at the onset of illness does not seem to have benefit. antioxidant vitamin supplementation has similar inconsistent data, ranging from slight benefit to harm. ${ }^{2,116}$ After a large Cochrane review in 2012 found a significant increase in all-cause mortality associated with vitamin $\mathrm{E}$ and beta-carotene, ${ }^{117}$ the USPSTF made a specific recommendation against supplementation of these vitamins for the prevention of cardiovascular disease or cancer (grade D). ${ }^{118}$ Given its limited risk for harm, vitamin C was excluded from this recommendation.

\section{Vitamin A}

I Vitamers: Retinol; retinal; retinyl esters; provitamin A carotenoids (beta-carotene, alpha-carotene, beta-cryptoxanthin)

I Physiologic role: Essential for vision and corneal development. Also involved in general cell differentiation and immune function I Dietary sources: Liver, fish oil, dairy, and fortified cereals. Provitamin A sources: leafy green vegetables, orange/yellow vegetables, tomato products, fruits, and vegetable oils

Retinoids and their precursors, carotenoids, serve a critical function in vision, as well as regulating cell differentiation and proliferation throughout the body. ${ }^{2}$ While evidence suggests mortality benefit of supplementation in populations at risk of deficiency, ${ }^{45}$ wide-ranging studies have found either inconsistent benefit or outright harms in the developed world.

THE TAKEAWAY: Given the USPSTF grade " $\mathrm{D}$ " recommendation and concern for potential harms, supplementation is not recommended in healthy patients without risk factors for deficiency. ${ }^{2}$

\section{Vitamin E}

I Vitamers: Tocopherols (alpha-, beta-, gamma-, delta-); tocotrienol (alpha-, beta-, gamma-, delta-)

I Physiologic role: Antioxidant; protects polyunsaturated fats from free radical oxidative damage. Involved in immune function, cell signaling, and regulation of gene expression

I Dietary sources: Nuts, seeds, vegetable oil, green leafy vegetables, and fortified cereals

Vitamin $E$ is the collective name of 8 compounds; alpha-tocopherol is the physiologically active form. Vitamin $\mathrm{E}$ is involved with cell proliferation as well as endothelial and platelet function. ${ }^{2}$

THE TAKEAWAY: Vitamin E supplementation's effects on cancer, cardiovascular disease, ophthalmologic disorders, and cognition have been investigated; data is either lacking to support a benefit or demonstrates harms as outlined above. Given this and the USPSTF grade " $\mathrm{D}$ " recommendation, supplementation is not recommended in healthy patients. $^{2}$

\section{Vitamin C}

Vitamers: Ascorbic acid

I Physiologic role: Required for synthesis of collagen, L-carnitine, and some neurotransmitters. Also involved in protein metabolism Dietary sources: Primarily in fruits and vegetables: citrus, tomato, potatoes, red/green peppers, kiwi fruit, broccoli, strawberries, brussels sprouts, cantaloupe, and fortified cereals

Ascorbic acid is a required cofactor for biosynthesis of collagen, neurotransmitters, and protein metabolism. ${ }^{2}$ In addition to the shared hypothesized benefits of antioxidants, vitamin $\mathrm{C}$ supplementation has undergone extensive research into its potential role in augmenting the immune system and preventing the common cold. Systematic reviews have found daily vitamin $C$ supplementation of at least $200 \mathrm{mg}$ did not affect the incidence of the common cold in healthy adults but may shorten duration and could be of benefit in those exposed to extreme physical exercise or cold ${ }^{48}$ Vitamin C supplementation at the onset of illness does not seem to have benefit. ${ }^{48}$ Data is insufficient to draw conclusions about a potential effect on pneumonia incidence or severity. ${ }^{11,120}$

THE TAKEAWAY: Overall, data remain inconclusive as to potential benefits of vitamin C supplementation, although risks of potential harms are likely low.

\section{Vitamin D}

I Vitamers: Cholecalciferol (D3); ergocalciferol (D2)

I Physiologic role: Hydroxylation in liver and kidney required to activate. Promotes dietary 
calcium absorption, enables normal bone mineralization. Also involved in modulation of cell growth, and neuromuscular and immune function

I Dietary sources: Few natural dietary sources, which include fatty fish, fish liver oils; small amount in beef liver, cheese, egg yolks. Primary sources include fortified milk and endogenous synthesis in skin with UV exposure

Calciferol is a fat-soluble vitamin required for calcium and bone homeostasis. It is not naturally available in many foods but is primarily produced endogenously in the skin with ultraviolet light exposure. ${ }^{2}$

Bone density and fracture risk reduction are the most often cited benefits of vitamin D supplementation, but this has not been demonstrated consistently in RCTs. Multiple systematic reviews showing inconsistent benefit of vitamin $\mathrm{D}$ (with or without calcium) on fracture risk led the USPSTF to conclude that there is insufficient evidence (grade I) to issue a recommendation on vitamin $\mathrm{D}$ and calcium supplementation for primary prevention of fractures in postmenopausal women. ${ }^{49-51}$ Despite some initial evidence suggesting a benefit of vitamin $D$ supplementation on falls reduction, 3 recent systematic reviews did not demonstrate this in community-dwelling elders, ${ }^{54-56}$ although a separate Cochrane review did suggest a reduction in rate of falls among institutionalized elders. ${ }^{57}$

THE TAKEAWAY: Given these findings, the USPSTF has recommended against (grade D) vitamin $\mathrm{D}$ supplementation to prevent falls in community-dwelling elders. ${ }^{55}$

I Beyond falls. While the vitamin D receptor is expressed throughout the body and observational studies have suggested a correlation between vitamin D status and many outcomes, extensive RCT data has generally failed to demonstrate extraskeletal benefits from supplementation. Meta-analysis data have demonstrated potential reductions in acute respiratory infection rates and asthma exacerbations with vitamin D supplementation. There is also limited evidence suggesting a reduction in preeclampsia and low-birthweight infant risk with vitamin D supplementation in pregnancy. However, several large meta-analyses and systematic reviews have investigated vitamin D supplementation's effect on all-cause mortality and found no consistent data to support an association. . $^{41,58-62}$

Multiple systematic reviews have investigated and found high-quality evidence demonstrating no association between vitamin D supplementation and cancer ${ }^{41,63-66,21}$ or cardiovascular disease risk. ${ }^{41,70,71}$ There is high-quality data showing no benefit of vitamin D supplementation for multiple additional diseases, including diabetes, cognitive decline, depression, pain, obesity, and liver disease. ${ }^{43,72-75,85-90,122}$

THE TAKEAWAY: Due to poor availability in breastmilk, the American Academy of Pediatrics (AAP) recommends supplementing exclusively breastfed infants with $400 \mathrm{IU} / \mathrm{d}$ of vitamin D to prevent rickets. ${ }^{123}$ RCT data support high-dose supplementation of lactating women $(6400 \mathrm{IU} / \mathrm{d})$ as an alternative strategy to supplementation of the infant. ${ }^{124}$ The AAP recommends that all nonbreastfeeding infants and older children ingesting $<1000 \mathrm{~mL} / \mathrm{d}$ of vitamin D-fortified formula or milk should also be supplemented with $400 \mathrm{IU} / \mathrm{d}$ of vitamin D. ${ }^{123}$ Despite these universal recommendations for supplementation, evidence is mixed on the effect of vitamin D supplementation on bone health in children. ${ }^{52,53}$

Although concerns about vitamin D supplementation and increased risk of urolithiasis and hypercalcemia have been raised, ${ }^{51,62,121}$ systematic reviews have not demonstrated significant, clinically relevant risks, even with high-dose supplementation $(>2800 \mathrm{IU} / \mathrm{d})$. $^{125,126}$

\section{Vitamin $\mathrm{K}$}

I Vitamers: Phylloquinone (K1); menaquinones (K2)

I Physiologic role: Coenzyme for synthesis of proteins involved in hemostasis and bone metabolism

I Dietary sources: Phylloquinone is found in green leafy vegetables, vegetable oils, some fruits, meat, dairy, and eggs. Menaquinone is produced by gut bacteria and present in fermented foods
The AAP recommends supplementing exclusively breastfed infants with $400 \mathrm{IU} / \mathrm{d}$ of vitamin $D$ to prevent rickets. 


\section{$>$}

Children taking multivitamins were often found to have excess levels of potentially harmful nutrients, such as retinol, zinc, and folic acid.
Vitamin $\mathrm{K}$ includes 2 groups of similar compounds: phylloquinone and menaquinones. Unlike other fat-soluble vitamins, vitamin $\mathrm{K}$ is rapidly metabolized and has low tissue storage. $^{2}$

Administration of vitamin $\mathrm{K} 0.5$ to $1 \mathrm{mg}$ intramuscularly (IM) to newborns is standard of care for the prevention of vitamin K deficiency bleeding (VKDB). This is supported by RCT data demonstrating a reduction in classic VKDB (occurring within 7 days) ${ }^{91}$ and epidemiologic data from various countries showing a reduction in late-onset VKDB with vitamin $\mathrm{K}$ prophylaxis programs. ${ }^{127}$ Oral dosing appears to reduce the risk of VKDB in the setting of parental refusal but is less effective than IM dosing. ${ }^{128,129}$

Vitamin K's effects on bone density and fracture risk have also been investigated. Systematic reviews have demonstrated a reduction in fracture risk with vitamin $\mathrm{K}$ supplementation, ${ }^{92,93}$ and European and Asian regulatory bodies have recognized a potential benefit on bone health. ${ }^{2}$ The FDA considers the evidence insufficient at this time to support such a claim. ${ }^{2}$ Higher dietary vitamin $\mathrm{K}$ consumption has been associated with lower risk of cardiovascular disease in observational studies ${ }^{94}$ and supplementation was associated with improved disease measures, ${ }^{130}$ but no patient-oriented outcomes have been demonstrated. ${ }^{131}$

THE TAKEAWAY: The administration of vitamin K 0.5 to $1 \mathrm{mg}$ intramuscularly (IM) to newborns is standard of care for the prevention of VKDB. Vitamin K may lead to a reduction in fracture risk, but the FDA considers the evidence insufficient. Vitamin K's potential link to a lowered risk of cardiovascular disease has not been demonstrated with patient-oriented outcomes. Vitamin $\mathrm{K}$ has low potential for toxicity, although its interaction with vitamin $\mathrm{K}$ antagonists (ie, warfarin) is clinically relevant.

\section{MULTIVITAMINS}

Multivitamins are often defined as a supplement containing 3 or more vitamins and minerals but without herbs, hormones, or drugs. ${ }^{132}$ Many multivitamins do contain ad- ditional substances, and some include levels of vitamins that exceed the RDA or even the established tolerable upper intake level. ${ }^{133}$

A 2013 systematic review found limited evidence to support any benefit from multivitamin supplementation. ${ }^{41}$ Two included RCTs demonstrated a narrowly significant decrease in cancer rates among men, but saw no effect in women or the combined population. ${ }^{134,135}$ This benefit appears to disappear at 5 years of follow-up. ${ }^{136}$ RCT data have shown no benefit of multivitamin use on cognitive function, ${ }^{95}$ and high-quality data suggest there is no effect on all-cause mortality. ${ }^{137}$ Given this lack of supporting evidence, the USPSTF has concluded that there is insufficient evidence (grade I) to recommend vitamin supplementation in general to prevent cardiovascular disease or cancer. $^{41}$

The use of prenatal multivitamins is generally recommended in the pregnancy and preconception period and has been associated with reduced risk of autism spectrum disorders, pediatric cancer rates, small-forgestational-age infants, and multiple birth defects in offspring; however, studies have not examined if this benefit exceeds that of folate supplementation alone. ${ }^{138-140}$ AAP does not recommend multivitamins for children with a well-balanced diet. ${ }^{141}$ Of concern, children taking multivitamins were often found to have excess levels of potentially harmful nutrients such as retinol, zinc, and folic acid. ${ }^{142}$

THE TAKEAWAY: There is limited evidence to support any benefit from multivitamin supplementation. Prenatal multivitamins are generally recommended in the pregnancy and preconception period. Overall, the risks of multivitamins are minimal, although that risk is dependent on the multivitamin's constituent components. ${ }^{143}$ Components such as vitamin $\mathrm{K}$ may interact with a patient's medications, and multivitamins have been shown to reduce the circulating levels of antiretrovirals. ${ }^{144}$ Specifically, multivitamins with iron should be avoided in men and postmenopausal women, and safe medication storage should be practiced as multivitamins with iron are a leading cause of poisoning in children. ${ }^{2}$ 


\section{SUMMARY}

Vitamin supplementation in the developed world remains common despite a paucity of RCT data supporting it. Supplementation of folate in women planning to conceive, vitamin $\mathrm{D}$ in breastfeeding infants, and vitamin $\mathrm{K}$ in newborns are well supported by clinical evidence. Otherwise, there is limited evidence supporting clinically significant benefit from supplementation in healthy patients with well-balanced diets-and in the case of vitamins A and E, there may be outright harms.

JFP

CORRESPONDENCE

Joel Herness, MD, 4700 North Las Vegas Boulevard, Nellis AFB, NV 89191; joelherness@gmail.com

\section{REFERENCES}

1. Half of Americans take vitamins regularly. Accessed June 16, 2020 https://news.gallup.com/poll/166541/half-americans-vitaminsregularly.aspx

2. National Institutes of Health. Vitamin and mineral supplement fact sheets. Published 2020. Accessed May 26, 2020. https://ods.od.nih. gov/factsheets/list-VitaminsMinerals/

3. Day E, Bentham PW, Callaghan R, et al. Thiamine for prevention and treatment of Wernicke-Korsakoff syndrome in people who abuse alcohol. Cochrane Database Syst Rev. 2013;(7):CD004033. doi:10.1002/14651858.CD004033.pub3

4. DiNicolantonio JJ, Niazi AK, Lavie CJ, et al. Thiamine supplementation for the treatment of heart failure: a review of the literature. Congest Heart Fail. 2013;19:214-222. doi:10.1111/chf.12037

5. Rodríguez-Martín JL, Qizilbash N, López-Arrieta JM. Thiamine for Alzheimer's disease. Cochrane Database Syst Rev. 2001;(2):CD001498. doi:10.1002/14651858.CD001498

6. Schoenen J, Jacquy J, Lenaerts M. Effectiveness of high-dose riboflavin in migraine prophylaxis. A randomized controlled trial. Neurology. 1998;50:466-470. doi:10.1212/wnl.50.2.466

7. Johansson M, Relton C, Ueland PM, et al. Serum B vitamin levels and risk of lung cancer. JAMA. 2010;303:2377-2385. doi:10.1001/ jama.2010.808

8. Kabat GC, Miller AB, Jain M, et al. Dietary intake of selected B vitamins in relation to risk of major cancers in women. $\mathrm{Br} J$ Cancer 2008;99:816-821. doi:10.1038/sj.bjc.6604540

9. Zschäbitz S, Cheng T-YD, Neuhouser ML, et al. B vitamin intakes and incidence of colorectal cancer: results from the Women's Health Initiative Observational Study cohort. Am J Clin Nutr. 2013;97:332-343. doi:10.3945/ajcn.112.034736

10. de Vogel S, Dindore V, van Engeland M, et al. Dietary folate, methionine, riboflavin, and vitamin B-6 and risk of sporadic colorectal cancer. J Nutr. 2008;138:2372-2378. doi:10.3945/jn.108.091157

11. Bassett JK, Hodge AM, English DR, et al. Dietary intake of B vitamins and methionine and risk of lung cancer. Eur J Clin Nutr. 2012;66:182-187. doi:10.1038/ejcn.2011.157

12. McRae MP. Treatment of hyperlipoproteinemia with pantethine: a review and analysis of efficacy and tolerability. Nutr Res. 2005; 25:319-333.

13. Saposnik G, Ray JG, Sheridan P, et al; Heart Outcomes Prevention Evaluation 2 Investigators. Homocysteine-lowering therapy and stroke risk, severity, and disability: additional findings from the HOPE 2 trial. Stroke. 2009;40:1365-1372. doi:10.1161/ STROKEAHA.108.529503

14. Larsson SC, Orsini N, Wolk A. Vitamin B6 and risk of colorectal cancer: a meta-analysis of prospective studies. JAMA. 2010;303 1077-1083. doi:10.1001/jama.2010.263

15. Mocellin S, Briarava M, Pilati P. Vitamin B6 and cancer risk: a field synopsis and meta-analysis. J Natl Cancer Inst. 2017;109:1-9. doi:10.1093/jnci/djw230

16. Ebbing M, Bønaa KH, Nygård $\mathrm{O}$, et al. Cancer incidence and mortality after treatment with folic acid and vitamin B12. JAMA 2009;302:2119-2126. doi:10.1001/jama.2009.1622

17. Malouf R, Grimley Evans J. The effect of vitamin B6 on cognition. Cochrane Database Syst Rev. 2003;(4):CD004393. doi:10.1002/14651858.CD004393

18. Balk EM, Raman G, Tatsioni A, et al. Vitamin B6, B12, and folic acid supplementation and cognitive function: a systematic review of randomized trials. Arch Intern Med. 2007;167:21-30. doi:10.1001/ archinte.167.1.21

19. American College of Obstetrics and Gynecology. ACOG Practice Bulletin: nausea and vomiting of pregnancy. Obstet Gynecol. 2004;103:803-814

20. Matthews A, Dowswell T, Haas DM, et al. Interventions for nausea and vomiting in early pregnancy. Cochrane Database Syst Rev. 2010;(9):CD007575. doi:10.1002/14651858.CD007575.pub2

21. US Preventive Services Task Force. Folic acid for the prevention of neural tube defects: US Preventive Services Task Force recommendation statement. Ann Intern Med. 2009;150:626-631.

22. De-Regil LM, Peña-Rosas JP, Fernández-Gaxiola AC, et al. Effects and safety of periconceptional oral folate supplementation for preventing birth defects. Cochrane Database Syst Rev. 2015;(12):CD007950. doi:10.1002/14651858.CD007950. pub3

23. Surén P, Roth $C$, Bresnahan M, et al. Association between maternal use of folic acid supplements and risk of autism spectrum disorders in children. JAMA. 2013;309:570-577. doi:10.1001/ jama.2012.155925

24. Schmidt RJ, Tancredi DJ, OzonoffS, et al. Maternal periconceptiona folic acid intake and risk of autism spectrum disorders and developmental delay in the CHARGE (CHildhood Autism Risks from Genetics and Environment) case-control study. Am J Clin Nutr. 2012;96:80-89. doi:10.3945/ajcn.110.004416

25. Levine SZ, Kodesh A, Viktorin A, et al. Association of maternal use of folic acid and multivitamin supplements in the periods before and during pregnancy with the risk of autism spectrum disorde in offspring. JAMA Psychiatry. 2018;75:176-184. doi:10.1001/ jamapsychiatry.2017.4050

26. Virk J, Liew Z, Olsen J, et al. Preconceptional and prenata supplementary folic acid and multivitamin intake and autism spectrum disorders. Autism. 2016;20:710-718. doi:10.1177/1362361315604076

27. Vollset SE, Clarke R, Lewington S, et al. Effects of folic acid supplementation on overall and site-specific cancer incidence during the randomised trials: meta-analyses of data on 50,000 individuals. Lancet. 2013;381:1029-1036. doi:10.1016/S0140-6736(12)62001-7

28. Passarelli MN, Barry EL, Rees JR, et al. Folic acid supplementation and risk of colorectal neoplasia during long-term follow-up of a randomized clinical trial. Am J Clin Nutr. 2019;110:903-911. doi:10.1093/ajcn/nqz160

29. Oliai Araghi S, Kiefte-de Jong JC, van Dijk SC, et al. Folic acid and vitamin $\mathrm{B} 12$ supplementation and the risk of cancer: long-term follow-up of the B vitamins for the Prevention of Osteoporotic Fractures (B-PROOF) Trial. Cancer Epidemiol Biomarkers Prev. 2019;28:275-282. doi:10.1158/1055-9965.EPI-17-1198

30. Wan Ismail WR, Abdul Rahman R, et al. The protective effect of maternal folic acid supplementation on childhood cancer: a systematic review and meta-analysis of case-control studies. J Prev Med Public Health. 2019;52:205-213. doi:10.3961/jpmph.19.020

31. Martí-Carvajal AJ, Solà I, Lathyris D, et al. Homocysteine lowering interventions for preventing cardiovascular events. Cochrane Database Syst Rev. 2009;(4):CD006612. doi:10.1002/14651858. CD006612.pub2

32. Wang Y, Jin Y, Wang Y, et al. The effect of folic acid in patients with cardiovascular disease: A systematic review and meta-analysis. Medicine. 2019;98:e17095. doi:10.1097/MD.0000000000017095

33. Malouf R, Areosa Sastre A. Vitamin B12 for cognition. Cochrane Database Syst Rev. 2003;(3):CD004326. doi:10.1002/14651858. CD004326

34. Malouf R, Grimley Evans J. Folic acid with or without vitamin $\mathrm{B} 12$ for the prevention and treatment of healthy elderly and demented people. Cochrane Database Syst Rev. 2008;(4):CD004514. doi:10.1002/14651858.CD004514.pub2

35. Suh SW, Kim HS, Han JH, et al. Efficacy of vitamins on cognitive function of non-demented people: a systematic review and metaanalysis. Nutrients. 2020;12(4). doi:10.3390/nu12041168

36. Stone KL, Lui L-Y, Christen WG, et al. Effect of combination folic acid, vitamin B6, and vitamin B12 supplementation on fracture risk in women: a randomized, controlled trial. J Bone Miner Res. 2017;32:2331-2338. doi:10.1002/jbmr.3229
Safe medication storage should be practiced, as multivitamins with iron are a leading cause of poisoning in children. 
37. Age-related Eye Disease Study Research Group. A randomized, placebo-controlled, clinical trial of high-dose supplementation with vitamins $\mathrm{C}$ and $\mathrm{E}$, beta carotene, and zinc for age-related macular degeneration and vision loss: AREDS report no. 8. Arch Ophthalmol.2001;119:1417-1436. doi:10.1001/archopht.119.10.1417

38. Park Y, Spiegelman D, Hunter DJ, et al. Intakes of vitamins A, C, and E and use of multiple vitamin supplements and risk of colon cancer: a pooled analysis of prospective cohort studies. Cancer Causes Control. 2010;21:1745-1757. doi:10.1007/s10552-010-9549-у

39. Koushik A, Wang M, Anderson KE, et al. Intake of vitamins A, C, and $\mathrm{E}$ and folate and the risk of ovarian cancer in a pooled analysis of 10 cohort studies. Cancer Causes Control. 2015;26:1315-1327. doi:10.1007/s10552-015-0626-0

40. Lin J, Cook NR, Albert C, et al. Vitamins C and E and beta carotene supplementation and cancer risk: a randomized controlled trial. J Natl Cancer Inst. 2009;101:14-23. doi:10.1093/jnci/djn438

41. Fortmann SP, Burda BU, Senger CA, et al. Vitamin and mineral supplements in the primary prevention of cardiovascular disease and cancer: an updated systematic evidence review for the US Preventive Services Task Force. Ann Intern Med. 2013;159:824-834. doi:10.7326/0003-4819-159-12-201312170-00729

42. Mathew MC, Ervin A-M, Tao J, et al. Antioxidant vitamin supplementation for preventing and slowing the progression of agerelated cataract. Cochrane Database Syst Rev. 2012;(6):CD004567. doi:10.1002/14651858.CD004567.pub2

43. Butler M, Nelson VA, Davila H, et al. Over-the-counter supplement interventions to prevent cognitive decline, mild cognitive impairment, and clinical Alzheimer-type dementia: a systematic review. Ann Intern Med. 2018;168:52-62. doi:10.7326/M17-1530

44. Crandall C. Vitamin A intake and osteoporosis: a clinical review. J Womens Health (Larchmt). 2004;13:939-953. doi:10.1089/ jwh.2004.13.939

45. Kranz S, Pimpin L, Fawzi W, et al. Mortality benefits of vitamin A are not affected by varying frequency, total dose, or duration of supplementation. Food Nutr Bull. 2017;38:260-266. doi:10.1177/0379572117696663

46. Miller ER, Pastor-Barriuso R, Dalal D, et al. Meta-analysis: highdosage vitamin E supplementation may increase all-cause mortality. Ann Intern Med. 2005;142:37-46. doi:10.7326/0003-4819142-1-200501040-00110

47. Klein EA, Thompson IM, Tangen CM, et al. Vitamin E and the risk of prostate cancer: the Selenium and Vitamin E Cancer Prevention Trial (SELECT). JAMA. 2011;306:1549-1556. doi:10.1001/ jama.2011.1437

48. Hemilä H, Chalker E. Vitamin C for preventing and treating the common cold. Cochrane Database Syst Rev. 2013;(1):CD000980. doi:10.1002/14651858.CD000980.pub4

49. Avenell A, Mak JCS, O'Connell D. Vitamin D and vitamin D analogues for preventing fractures in post-menopausal women and older men. Cochrane Database Syst Rev. 2014;(4):CD000227. doi:10.1002/14651858.CD000227.pub4

50. Zhao J-G, Zeng X-T, Wang J, et al. Association between calcium or vitamin $\mathrm{D}$ supplementation and fracture incidence in community-dwelling older adults: a systematic review and meta-analysis. JAMA. 2017;318:2466-2482. doi:10.1001/jama.2017.19344

51. Kahwati LC, Weber RP, Pan H, et al. Vitamin D, calcium, or combined supplementation for the primary prevention of fractures in community-dwelling adults: evidence report and systematic review for the US Preventive Services Task Force. JAMA. 2018;319: 1600-1612. doi:10.1001/jama.2017.21640

52. Winzenberg T, Powell S, Shaw KA, et al. Effects of vitamin D supplementation on bone density in healthy children: systematic review and meta-analysis. BMJ.2011;342:c7254. doi:10.1136/bmj.c7254

53. Winzenberg TM, Powell S, Shaw KA, et al. Vitamin D supplementation for improving bone mineral density in children. Cochrane Database Syst Rev. 2010;(10):CD006944. doi:10.1002/14651858. CD006944.pub2

54. Bolland MJ, Grey A, Gamble GD, et al. Vitamin D supplementation and falls: a trial sequential meta-analysis. Lancet Diabetes Endocrinol. 2014;2:573-580. doi:10.1016/S2213-8587(14)70068-3

55. Guirguis-Blake JM, Michael YL, Perdue LA, et al. Interventions to prevent falls in older adults: updated evidence report and systematic review for the US Preventive Services Task Force. JAMA. 2018;319:1705-1716. doi:10.1001/jama.2017.21962

56. Gillespie LD, Robertson MC, Gillespie WJ, et al. Interventions for preventing falls in older people living in the community. Cochrane Database Syst Rev. 2012;(9):CD007146. doi:10.1002/14651858. CD007146.pub3

57. Cameron ID, Dyer SM, Panagoda CE, et al. Interventions for preventing falls in older people in care facilities and hospitals. $\mathrm{Co}$ - chrane Database Syst Rev. 2018;9:CD005465. doi:10.1002/14651858. CD005465.pub4

58. Chung M, Balk EM, Brendel M, et al. Vitamin D and calcium: a systematic review of health outcomes. Evid Rep Technol Assess (Full Rep). 2009;(183):1-420.

59. Autier P, Gandini S. Vitamin D supplementation and total mortality: a meta-analysis of randomized controlled trials. Arch Intern Med. 2007;167:1730-1737. doi:10.1001/archinte.167.16.1730

60. Zhang Y, Fang F, Tang J, et al. Association between vitamin D supplementation and mortality: systematic review and meta-analysis. BMJ. 2019;366:14673. doi:10.1136/bmj.14673

61. Cauley JA, Chlebowski RT, Wactawski-Wende J, et al. Calcium plus vitamin D supplementation and health outcomes five years after active intervention ended: the Women's Health Initiative. JWomens Health (Larchmt). 2013;22:915-929. doi:10.1089/jwh.2013.4270

62. Bjelakovic G, Gluud LL, Nikolova D, et al. Vitamin D supplementation for prevention of mortality in adults. Cochrane Database Syst Rev. 2014;(1):CD007470. doi:10.1002/14651858.CD007470.pub3

63. Zhou L, Chen B, Sheng L, et al. The effect of vitamin D supplementation on the risk of breast cancer: a trial sequential meta-analysis. Breast Cancer Res Treat. 2020;182:1-8. doi:10.1007/s10549-02005669-4

64. Shahvazi S, Soltani S, Ahmadi SM, et al A. The effect of vitamin D supplementation on prostate cancer: a systematic review and meta-analysis of clinical trials. Horm Metab Res. 2019;51:11-21. doi:10.1055/a-0774-8809

65. Buttigliero C, Monagheddu C, Petroni P, et al. Prognostic role of vitamin d status and efficacy of vitamin D supplementation in cancer patients: a systematic review. Oncologist. 2011;16:1215-1227. doi:10.1634/theoncologist.2011-0098

66. Cortés-Jofré M, Rueda J-R, Asenjo-Lobos C, et al. Drugs for preventing lung cancer in healthy people. Cochrane Database Syst Rev. 2020;3:CD002141. doi:10.1002/14651858.CD002141.pub3

67. Elamin MB, Abu Elnour NO, Elamin KB, et al. Vitamin D and cardiovascular outcomes: a systematic review and meta-analysis. J Clin Endocrinol Metab. 2011;96:1931-1942. doi:10.1210/jc.20110398

68. Pittas AG, Chung M, Trikalinos T, et al. Systematic review: vitamin D and cardiometabolic outcomes. Ann Intern Med. 2010;152:307-314. doi:10.7326/0003-4819-152-5-201003020-00009

69. Ford JA, MacLennan GS, Avenell A, et al. Cardiovascular disease and vitamin D supplementation: trial analysis, systematic review, and meta-analysis. Am J Clin Nutr. 2014;100:746-755. doi:10.3945/ ajcn.113.082602

70. Beveridge LA, Struthers AD, Khan F, et al. Effect of vitamin D supplementation on blood pressure: a systematic review and metaanalysis incorporating individual patient data. JAMA Intern Med. 2015;175:745-754. doi:10.1001/jamainternmed.2015.0237

71. Qi D, Nie X, Cai J. The effect of vitamin D supplementation on hypertension in non-CKD populations: a systemic review and meta-analysis. Int J Cardiol. 2017;227:177-186. doi:10.1016/ j.ijcard.2016.11.040

72. Rutjes AW, Denton DA, Di Nisio M, et al. Vitamin and mineral supplementation for maintaining cognitive function in cognitively healthy people in mid and late life. Cochrane Database Syst Rev . 2018;12:CD011906. doi:10.1002/14651858.CD011906.pub2

73. Straube S, Derry S, Straube C, et al. Vitamin D for the treatment of chronic painful conditions in adults. Cochrane Database Syst Rev. 2015;(5):CD007771. doi:10.1002/14651858.CD007771.pub3

74. Zadro JR, Shirley D, Ferreira M, et al. Is vitamin D supplementation effective for low back pain? A systematic review and meta-analysis. Pain Physician. 2018;21:121-145.

75. Wu Z, Malihi Z, Stewart AW, et al. Effect of vitamin D supplementation on pain: a systematic review and meta-analysis. Pain Physician. 2016;19:415-427.

76. Palacios C, Kostiuk LK, Peña-Rosas JP. Vitamin D supplementation for women during pregnancy. Cochrane Database Syst Rev. 2019;7:CD008873. doi:10.1002/14651858.CD008873.pub4

77. Bi WG, Nuyt AM, Weiler $\mathrm{H}$, et al. Association between vitamin D supplementation during pregnancy and offspring growth, morbidity, and mortality: a systematic review and meta-analysis. JAMA Pediatr. 2018;172:635-645. doi:10.1001/jamapediatrics.2018.0302

78. Yepes-Nuñez JJ, Brożek JL, Fiocchi A, et al. Vitamin D supplementation in primary allergy prevention: Systematic review of randomized and non-randomized studies. Allergy. 2018;73:37-49. doi:10.1111/all.13241

79. Purswani JM, Gala P, Dwarkanath P, et al. The role of vitamin D in pre-eclampsia: a systematic review. BMC Pregnancy Childbirth. 2017;17:231. doi:10.1186/s12884-017-1408-3 
80. Khaing W, Vallibhakara SA-O, Tantrakul V, et al. Calcium and vitamin D supplementation for prevention of preeclampsia: a systematic review and network meta-analysis. Nutrients. 2017;9:1141 doi:10.3390/nu9101141

81. Palacios C, De-Regil LM, Lombardo LK, et al. Vitamin D supplementation during pregnancy: updated meta-analysis on maternal outcomes. J Steroid Biochem Mol Biol. 2016;164:148-155. doi:10.1016/j.jsbmb.2016.02.008

82. Litonjua AA, Carey VJ, Laranjo N, et al. Six-year follow-up of a trial of antenatal vitamin D for asthma reduction. $N$ Engl J Med. 2020;382:525-533. doi:10.1056/NEJMoa1906137

83. Martineau AR, Jolliffe DA, Hooper RL, et al. Vitamin D supplementation to prevent acute respiratory tract infections: systematic review and meta-analysis of individual participant data. $B M J$. 2017;356:16583. doi:10.1136/bmj.i6583

84. Jolliffe DA, Greenberg L, Hooper RL, et al. Vitamin D supplementation to prevent asthma exacerbations: a systematic review and meta-analysis of individual participant data. Lancet Respir Med. 2017;5:881-890. doi:10.1016/S2213-2600(17)30306-5

85. Chandler PD, Wang L, Zhang X, et al. Effect of vitamin D supplementation alone or with calcium on adiposity measures: a systematic review and meta-analysis of randomized controlled trials. Nutr Rev. 2015;73:577-593. doi:10.1093/nutrit/nuv012

86. Gowda U, Mutowo MP, Smith BJ, et al. Vitamin D supplementation to reduce depression in adults: meta-analysis of randomized controlled trials. Nutrition. 2015;31:421-429. doi:10.1016/ j.nut.2014.06.017

87. Li G, Mbuagbaw L, Samaan Z, et al. Efficacy of vitamin D supplementation in depression in adults: a systematic review. JClin Endocrinol Metab. 2014;99:757-767. doi:10.1210/jc.2013-3450

88. Pittas AG, Dawson-Hughes B, Sheehan P, et al. Vitamin D supplementation and prevention of type 2 diabetes. $N$ Engl J Med. 2019;381:520-530. doi:10.1056/NEJMoa1900906

89. Lee CJ, Iyer G, Liu Y, et al. The effect of vitamin D supplementation on glucose metabolism in type 2 diabetes mellitus: a systematic review and meta-analysis of intervention studies. J Diabetes Complicat. 2017;31:1115-1126. doi:10.1016/j.jdiacomp.2017.04.019

90. Bjelakovic G, Nikolova D, Bjelakovic M, et al. Vitamin D supplementation for chronic liver diseases in adults. Cochrane Database Syst Rev. 2017;11:CD011564. doi:10.1002/14651858.CD011564.pub2

91. Sankar MJ, Chandrasekaran A, Kumar P, et al. Vitamin Kprophylaxis for prevention of vitamin K deficiency bleeding: a systematic review. JPerinatol. 2016;36(suppl 1):S29-S35. doi:10.1038/jp.2016.30

92. Mott A, Bradley T, Wright K, et al. Effect of vitamin K on bone mineral density and fractures in adults: an updated systematic review and meta-analysis of randomised controlled trials. Osteoporos Int. 2019;30:1543-1559. doi:10.1007/s00198-019-04949-0

93. Cockayne S, Adamson J, Lanham-New S, et al. Vitamin K and the prevention of fractures: systematic review and meta-analysis of randomized controlled trials. Arch Intern Med. 2006;166:1256-1261. doi:10.1001/archinte.166.12.1256

94. Chen H-G, Sheng L-T, Zhang Y-B, et al. Association of vitamin K with cardiovascular events and all-cause mortality: a systematic review and meta-analysis. Eur J Nutr. 2019;58:2191-2205. doi:10.1007/ s00394-019-01998-3

95. Grodstein F, O'Brien J, Kang JH, et al. Long-term multivitamin supplementation and cognitive function in men: a randomized trial. Ann Intern Med. 2013;159:806-814. doi:10.7326/0003-4819 159-12-201312170-00006

96. Christen WG, Glynn RJ, Manson JE, et al. Effects of multivitamin supplement on cataract and age-related macular degeneration in a randomized trial of male physicians. Ophthalmology. 2014;121: 525-534. doi:10.1016/j.ophtha.2013.09.038

97. Holland S, Silberstein SD, Freitag F, et al. Evidence-based guideline update: NSAIDs and other complementary treatments for episodic migraine prevention in adults: report of the Quality Standards Subcommittee of the American Academy of Neurology and the American Headache Society. Neurology. 2012;78:1346-1353. doi:10.1212/ WNL.0b013e3182535d0c

98. Rumberger JA, Napolitano J, Azumano I, et al. Pantethine, a derivative of vitamin $\mathrm{B}(5)$ used as a nutritional supplement, favorably alters low-density lipoprotein cholesterol metabolism in low- to moderate-cardiovascular risk North American subjects: a tripleblinded placebo and diet-controlled investigation. Nutr Res. 2011;31: 608-615. doi:10.1016/j.nutres.2011.08.001

99. Evans M, Rumberger JA, Azumano I, et al. Pantethine, a derivative of vitamin B5, favorably alters total, LDL and non-HDL cholesterol in low to moderate cardiovascular risk subjects eligible for statin therapy: a triple-blinded placebo and diet-controlled investigation. Vasc Health Risk Manag. 2014;10:89-100. doi:10.2147/VHRM.S57116
100. Ebbing M, Bønaa KH, Arnesen E, et al. Combined analyses and extended follow-up of two randomized controlled homocysteine-lowering B-vitamin trials. J Intern Med. 2010;268:367-382. doi:10.1111/j.1365-2796.2010.02259.x

101. Toole JF, Malinow MR, Chambless LE, et al. Lowering homocysteine in patients with ischemic stroke to prevent recurrent stroke, myocardial infarction, and death: the Vitamin Intervention for Stroke Prevention (VISP) randomized controlled trial. JAMA. 2004;291:565-575. doi:10.1001/jama.291.5.565

102. Albert CM, Cook NR, Gaziano JM, et al. Effect of folic acid and B vitamins on risk of cardiovascular events and total mortality among women at high risk for cardiovascular disease: a randomized trial. JAMA. 2008;299:2027-2036. doi:10.1001/jama.299.17.2027

103. FDA. The FDA warns that biotin may interfere with lab tests: FDA Safety Communication. Accessed June 1, 2020. www.fda.gov/ medical-devices/safety-communications/update-fda-warnsbiotin-may-interfere-lab-tests-fda-safety-communication

104. National Toxicology Program. Identifying research needs for assessing safe use of high intakes of folic acid. Published 2015. Accessed June 7, 2020. https://ntp.niehs.nih.gov/ntp/ohat/ folicacid/final_monograph_508.pdf

105. Miller ER, JuraschekS, Pastor-Barriuso R, et al. Meta-analysis of folic acid supplementation trials on risk of cardiovascular disease and risk interaction with baseline homocysteine levels. Am J Cardiol. 2010;106:517-527. doi:10.1016/j.amjcard.2010.03.064

106. van Wijngaarden JP, Swart KMA, Enneman AW, et al. Effect of daily vitamin B-12 and folic acid supplementation on fracture incidence in elderly individuals with an elevated plasma homocysteine concentration: B-PROOF, a randomized controlled trial. Am JClin Nutr. 2014;100:1578-1586. doi:10.3945/ajcn.114.090043

107. Harirchian MH, Mohammadpour Z, Fatehi F, et al. A systematic review and meta-analysis of randomized controlled trials to evaluating the trend of cytokines to vitamin A supplementation in autoimmune diseases. Clin Nutr. 2019;38:2038-2044. doi:10.1016/ j.clnu.2018.10.026

108. Liu T, Zhong S, Liao X, et al. A meta-analysis of oxidative stress markers in depression. PLoS One. 2015;10:e138904. doi:10.1371/ journal.pone.0138904

109. Zeng J, Chen L, Wang Z, et al. Marginal vitamin A deficiency facilitates Alzheimer's pathogenesis. Acta Neuropathol. 2017;133: 967-982. doi:10.1007/s00401-017-1669-y

110. Omenn GS, Goodman GE, Thornquist MD, et al. Effects of a combination of beta carotene and vitamin A on lung cancer and cardiovascular disease. $N$ Engl J Med. 1996;334:1150-1155. doi:10.1056/ NEJM199605023341802

111. Kanellopoulou A, Riza E, Samoli E, et al. Dietary supplement use after cancer diagnosis in relation to total mortality, cancer mortality and recurrence: a systematic review and meta-analysis. Nutr Cancer. 2021;73:16-30. doi:10.1080/01635581.2020.1734215

112. Sunkara A, Raizner A. Supplemental vitamins and minerals for cardiovascular disease prevention and treatment. Methodist Debakey Cardiovasc J. 2019;15:179-184. doi:10.14797/mdcj-15-3-179

113. Zhang S, Hunter DJ, Forman MR, et al. Dietary carotenoids and vitamins A, C, and E and risk of breast cancer. J Natl Cancer Inst. 1999;91:547-556. doi:10.1093/jnci/91.6.547

114. He J, Gu Y, Zhang S. Vitamin A and breast cancer survival: a systematic review and meta-analysis. Clin Breast Cancer. 2018;18: e1389-e1400. doi:10.1016/j.clbc.2018.07.025

115. Harris HR, Orsini N, Wolk A. Vitamin C and survival among women with breast cancer: a meta-analysis. Eur J Cancer. 2014;50: 1223-1231. doi:10.1016/j.ejca.2014.02.013

116. Moser MA, Chun OK. Vitamin C and heart health: a review based on findings from epidemiologic studies. Int J Mol Sci. 2016;17. doi:10.3390/ijms17081328

117. Bjelakovic G, Nikolova D, Gluud LL, et al. Antioxidant supplements for prevention of mortality in healthy participants and patients with various diseases. Cochrane Database Syst Rev. 2012;(3):CD007176. doi:10.1002/14651858.CD007176.pub2

118. US Preventive Services Task Force. Vitamin supplementation to prevent cancer and CVD: preventive medication. Accessed May 21, 2020. www.uspreventiveservicestaskforce.org/uspstf/ recommendation/vitamin-supplementation-to-prevent-cancerand-cvd-counseling

119. Hemilä H, Louhiala P. Vitamin C for preventing and treating pneumonia. Cochrane Database Syst Rev. 2013;(8):CD005532. doi:10.1002/14651858.CD005532.pub3

120. Padhani ZA, Moazzam Z, Ashraf A, et al. Vitamin C supplementation for prevention and treatment of pneumonia. Cochrane Database Syst Rev. 2020;4:CD013134. doi:10.1002/14651858.CD013134.pub2

CONTINUED 
121. Bjelakovic G, Gluud LL, Nikolova D, et al. Vitamin D supplementation for prevention of cancer in adults. Cochrane Database Syst Rev. 2014;(6):CD007469. doi:10.1002/14651858.CD007469.pub2

122. Autier P, Mullie P, Macacu A, et al. Effect of vitamin D supplementation on non-skeletal disorders: a systematic review of meta-analyses and randomised trials. Lancet Diabetes Endocrinol. 2017;5: 986-1004. doi:10.1016/S2213-8587(17)30357-1

123. Wagner CL, Greer FR; American Academy of Pediatrics Section on Breastfeeding, American Academy of Pediatrics Committee on Nutrition. Prevention of rickets and vitamin D deficiency in infants, children, and adolescents. Pediatrics. 2008;122:1142-1152. doi:10.1542/peds.2008-1862

124. Hollis BW, Wagner CL, Howard CR, et al. Maternal versus infant vitamin D supplementation during lactation: a randomized controlled trial. Pediatrics. 2015;136:625-634. doi:10.1542/ peds.2015-1669

125. Malihi Z, Wu Z, Stewart AW, et al. Hypercalcemia, hypercalciuria, and kidney stones in long-term studies of vitamin D supplementation: a systematic review and meta-analysis. Am J Clin Nutr. 2016;104:1039-1051. doi:10.3945/ajcn.116.134981

126. Vogiatzi MG, Jacobson-Dickman E, DeBoer MD; Drugs, and Therapeutics Committee of The Pediatric Endocrine Society. Vitamin D supplementation and risk of toxicity in pediatrics: a review of current literature. J Clin Endocrinol Metab. 2014;99:1132-1141. doi:10.1210/jc.2013-3655

127. ZurynskiY, Grover CJ Jalaludin B, et al Vitamin K deficiency bleeding in Australian infants 1993-2017: an Australian Paediatric Surveillance Unit study. Arch Dis Child. 2020;105:433-438. doi:10.1136/ archdischild-2018-316424

128. Ng E, Loewy AD. Guidelines for vitamin K prophylaxis in newborns: a joint statement of the Canadian Paediatric Society and the College of Family Physicians of Canada. Can Fam Physician. 2018;64:736-739.

129. Araki S, Shirahata A. Vitamin K deficiency bleeding in infancy. $\mathrm{Nu}$ trients. 2020;12:780. doi:10.3390/nul2030780

130. Shea MK, Holden RM. Vitamin K status and vascular calcification: evidence from observational and clinical studies. Adv Nutr. 2012;3:158-165. doi:10.3945/an.111.001644

131. Hartley L, Clar C, Ghannam O, et al. Vitamin K for the primary prevention of cardiovascular disease. Cochrane Database Syst Rev. 2015;(9):CD011148. doi:10.1002/14651858.CD011148.pub2

132. Huang H-Y, Caballero B, Chang S, et al. Multivitamin/mineral supplements and prevention of chronic disease. Evid Rep Technol Assess (Full Rep). 2006;(139):1-117.

133. Bailey RL, Gahche JJ, Lentino CV, et al. Dietary supplement use in the United States, 2003-2006. J Nutr. 2011;141:261-266. doi:10.3945/ jn.110.133025

134. Gaziano JM, Sesso HD, Christen WG, et al. Multivitamins in the prevention of cancer in men: the Physicians' Health Study II randomized controlled trial. JAMA. 2012;308:1871-1880. doi:10.1001/ jama.2012.14641

135. Hercberg S, Galan P, Preziosi P, et al. The SUVI.MAX Study: a randomized, placebo-controlled trial of the health effects of antioxidant vitamins and minerals. Arch Intern Med. 2004;164: 2335-2342. doi:10.1001/archinte.164.21.2335

136. Hercberg S, Kesse-Guyot E, Druesne-Pecollo N, et al. Incidence of cancers, ischemic cardiovascular diseases and mortality during 5-year follow-up after stopping antioxidant vitamins and minerals supplements: a postintervention follow-up in the SU.VI.MAX Study. Int J Cancer. 2010;127:1875-1881. doi:10.1002/ijc.25201

137. Khan SU, Khan MU, Riaz H, et al. Effects of nutritional supplements and dietary interventions on cardiovascular outcomes: an umbrella review and evidence map. Ann Intern Med. 2019;171:190-198. doi:10.7326/M19-0341

138. Guo B-Q, Li H-B, Zhai D-S, et al. Maternal multivitamin supplementation is associated with a reduced risk of autism spectrum disorder in children: a systematic review and meta-analysis. Nutr Res. 2019;65:4-16. doi:10.1016/j.nutres.2019.02.003

139. Wolf HT, Hegaard HK, Huusom LD, et al. Multivitamin use and adverse birth outcomes in high-income countries: a systematic review and meta-analysis. Am J Obstet Gynecol. 2017;217:404.e1404.e30. doi:10.1016/j.ajog.2017.03.029

140. Goh YI, Bollano E, Einarson TR, et al. Prenatal multivitamin supplementation and rates of pediatric cancers: a metaanalysis. Clin Pharmacol Ther. 2007;81:685-691. doi:10.1038/ sj.clpt.6100100

141. HealthyChildren.org. Where we stand: vitamins. Accessed June $27, \quad 2020$. www.healthychildren.org/English/healthy-living/ nutrition/Pages/Where-We-Stand-Vitamins.aspx

142. Bailey RL, Catellier DJ, Jun S, et al. Total usual nutrient intakes of US children (under 48 months): findings from the Feeding Infants and Toddlers Study (FITS) 2016. J Nutr. 2018;148:1557S-1566S. doi:10.1093/jn/nxy042

143. Biesalski HK, Tinz J. Multivitamin/mineral supplements: rationale and safety. Nutrition. 2017;36:60-66. doi:10.1016/ j.nut.2016.06.003

144. Jalloh MA, Gregory PJ, Hein D, et al. Dietary supplement interactions with antiretrovirals: a systematic review. Int J STD AIDS. 2017;28:4-15. doi:10.1177/0956462416671087

\section{MEDJOBNETWORK,} Physician $\bullet$ NP/PA Career Center

\section{The first mobile job board for Physicians, NPs, and PAs}

Mobile Job Searches - access MedJobNetwork.com on the go from your smartphone or tablet

Advanced Search Capabilities - search for jobs by specialty, job title, geographic location, employer, and more

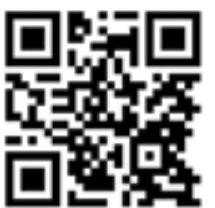


TABLE W1

Vitamin overview: RDA and toxicity risk ${ }^{2}$

Fat-soluble vitamins

\begin{tabular}{|c|c|c|c|c|c|}
\hline \multirow{2}{*}{ Vitamin } & \multicolumn{5}{|l|}{ RDA } \\
\hline & Infants & Pediatrics & Adults & Pregnancy & Breastfeeding \\
\hline A & $\begin{array}{l}400-500 \mathrm{mcg}^{\mathrm{RAE}} \mathrm{E}^{\mathrm{a}, \mathrm{b}} \\
\text { (breastmilk) } \\
\mathrm{UL}=0.6 \mathrm{mg} \mathrm{RAE^{ \textrm {b } }}\end{array}$ & $\begin{array}{l}300-600 \text { mcg } \mathrm{RAE}^{\mathrm{b}} \\
\text { (slice pumpkin pie; } \\
1 / 2 \text { cup spinach) } \\
\text { UL }=0.9 \text { mg RAE }^{\mathrm{b}}\end{array}$ & $\begin{array}{l}700-900 \text { mcg RAE } \\
\text { (1/2 sweet potato; } 12 \\
\text { oz herring) } \\
\text { UL = } 3 \text { mg RAE }{ }^{b}\end{array}$ & $\begin{array}{l}770 \text { mcg RAE }^{b} \\
\text { ( } 2.5 \text { cup French vanilla } \\
\text { ice cream) } \\
\text { UL = } 3 \text { mg RAE }{ }^{b}\end{array}$ & $\begin{array}{l}\text { 1200-1300 mcg RAE }{ }^{\mathrm{b}} \text { ( } 3 / 4 \text { oz beef liver) } \\
\mathrm{UL}=3 \mathrm{mg} \mathrm{RAE}^{\mathrm{b}}\end{array}$ \\
\hline D & $\begin{array}{l}400 \mathrm{IU}^{\mathrm{a}} \text { (4 servings } \\
\text { fortified cereal + } 2 \\
\text { eggs) } \\
\mathrm{UL}=1000 \mathrm{IU}\end{array}$ & $\begin{array}{l}600 \mathrm{IU} \text { (5 cups } \\
\text { vitamin D milk) } \\
\mathrm{UL}=1500-3000 \mathrm{IU}\end{array}$ & $\begin{array}{l}600-800 \mathrm{IU} \text { (3 oz } \\
\text { salmon; } 1 \text { cup } \\
\text { mushrooms) } \\
\mathrm{UL}=4000 \mathrm{IU}\end{array}$ & $\begin{array}{l}600 \mathrm{IU} \text { (3 oz rainbow } \\
\text { trout) } \\
\mathrm{UL}=4000 \mathrm{IU}\end{array}$ & $\begin{array}{l}600 \mathrm{IU}(1 / 2 \mathrm{tbsp} \text { cod liver oil) } \\
\mathrm{UL}=4000 \mathrm{IU}\end{array}$ \\
\hline $\mathrm{E}$ & $\begin{array}{l}4-5 \text { mg }^{\text {a }} \text { (breastmilk; } \\
1.5 \text { cups cooked } \\
\text { spinach) }\end{array}$ & $\begin{array}{l}6-15 \mathrm{mg} \text { ( } 1 \mathrm{oz} \\
\text { almonds; } 2 \mathrm{oz} \\
\text { sunflower seeds) } \\
\mathrm{UL}=200-600 \mathrm{mg}\end{array}$ & $\begin{array}{l}15 \mathrm{mg} \text { (4 oz hazelnuts) } \\
\mathrm{UL}=1000 \mathrm{mg}\end{array}$ & $\begin{array}{l}15 \text { mg (7 oz peanuts) } \\
U L=1000 \text { mg }\end{array}$ & $\begin{array}{l}19 \mathrm{mg} \text { (1 tbsp wheat germ oil) } \\
\mathrm{UL}=1000 \mathrm{mg}\end{array}$ \\
\hline K & $\begin{array}{l}2 \mathrm{mcg}^{\mathrm{a}} \text { (breastmilk; } \\
1.5 \mathrm{oz} \text { mozzarella } \\
\text { cheese) }\end{array}$ & $\begin{array}{l}30-60 \text { mcg }^{\text {a }} 1 \text { cup } \\
\text { carrot juice; } 1.5 \text { cups } \\
\text { edamame) }\end{array}$ & $\begin{array}{l}90-120 \text { mcg }^{\text {a }}(1 / 2 \text { cup } \\
\text { cooked broccoli; } 1 \text { cup } \\
\text { raw spinach) }\end{array}$ & $\begin{array}{l}90 \text { mcg }^{\mathrm{a}} \text { ( } 2 \text { tbsp turnip } \\
\text { greens) }\end{array}$ & $90 \mathrm{mcg}^{\mathrm{a}}$ (1.5 tbsp collard greens) \\
\hline
\end{tabular}

Water-soluble vitamins

\begin{tabular}{|c|c|c|c|c|c|}
\hline \multirow[t]{2}{*}{ Vitamin } & \multicolumn{5}{|l|}{ RDA } \\
\hline & Infants & Pediatrics & Adults & Pregnancy & Breastfeeding \\
\hline B1 & $\begin{array}{l}0.2-0.3 \mathrm{mg}^{\mathrm{a}} \\
\text { (breastmilk; } 1 / 2 \text { cup } \\
\text { acorn squash) }\end{array}$ & $\begin{array}{l}0.5-0.9 \mathrm{mg} \text { ( } 1 \text { cup } \\
\text { egg noodles; } 1 \text { cup } \\
\text { black beans }\end{array}$ & $\begin{array}{l}1.1-1.2 \mathrm{mg} \text { ( } 1 \text { serving } \\
\text { fortified cereal) }\end{array}$ & $\begin{array}{l}1.4 \mathrm{mg} \text { ( } 1 / 2 \text { cup white } \\
\text { rice) }\end{array}$ & $1.4 \mathrm{mg}$ ( $12 \mathrm{oz}$ cooked trout) \\
\hline B2 & $\begin{array}{l}0.3-0.4 \mathrm{mg}^{\mathrm{a}} \\
\text { (breastmilk; } 2 \text { eggs) }\end{array}$ & $\begin{array}{l}0.4-0.6 \mathrm{mg} \text { ( } 2 \text { cups } \\
\text { quinoa; } 6 \text { oz Swiss } \\
\text { cheese) }\end{array}$ & $\begin{array}{l}\text { 1.1-1.3 mg ( } 1 \text { cup cooked } \\
\text { oats; } 1 \text { serving cereal) }\end{array}$ & $1.4 \mathrm{mg}$ (5 oz almonds) & $1.6 \mathrm{mg}$ (12 oz steak) \\
\hline B3 & $\begin{array}{l}2-4 \text { mga }^{\text {a }} \text { (breastmilk; } \\
1 \text { cup brown rice) }\end{array}$ & $\begin{array}{l}6-12 \mathrm{mg} \text { ( } 3 \text { oz pork } \\
\text { tenderloin; } 5 \mathrm{oz} \\
\text { cooked salmon) } \\
\mathrm{UL}=10-20 \mathrm{mg}\end{array}$ & $\begin{array}{l}14-16 \mathrm{mg} \text { ( } 5 \text { oz turkey } \\
\text { breast; } 3 \text { cups white rice) } \\
\text { UL }=35 \mathrm{mg}\end{array}$ & $\begin{array}{l}18 \mathrm{mg} \text { ( } 1 \text { cup marinara } \\
\text { sauce) } \\
\mathrm{UL}=35 \mathrm{mg}\end{array}$ & $\begin{array}{l}17 \text { mg (9 oz ground beef) } \\
\mathrm{UL}=35 \mathrm{mg}\end{array}$ \\
\hline B5 & $\begin{array}{l}1.7-1.8 \mathrm{mg}^{\mathrm{a}} \\
\text { (breastmilk; } 4 \mathrm{oz} \\
\text { chicken breast) }\end{array}$ & $\begin{array}{l}2-4 \mathrm{mg}^{\mathrm{a}}(0.25-0.5 \\
\text { cup sunflower } \\
\text { seeds) }\end{array}$ & $\begin{array}{l}5 \mathrm{mg}^{\mathrm{a}} \text { (fortified breakfast } \\
\text { cereal) }\end{array}$ & 6 mga $^{\text {a }} 6$ cups broccoli) & $7 \mathrm{mg}^{\mathrm{a}}$ (3.5 avocados) \\
\hline B6 & $\begin{array}{l}0.1-0.3 \mathrm{mg}^{\mathrm{a}} \\
\text { (breastmilk; } 3 \mathrm{oz} \\
\text { ground beef) }\end{array}$ & $\begin{array}{l}0.5-1 \mathrm{mg} \text { ( } 3 \mathrm{oz} \\
\text { chicken breast; } 3 \\
\text { oz cooked tuna) } \\
\text { UL = } 30-40 \mathrm{mg}\end{array}$ & $\begin{array}{l}1.3-1.7 \mathrm{mg} \text { ( } 1-1.5 \text { cups } \\
\text { chickpeas) } \\
\mathrm{UL}=100 \mathrm{mg}\end{array}$ & $\begin{array}{l}1.9 \mathrm{mg} \text { (9 oz salmon) } \\
\mathrm{UL}=100 \mathrm{mg}\end{array}$ & $\begin{array}{l}2 \mathrm{mg} \text { (6 oz beef liver) } \\
\mathrm{UL}=100 \mathrm{mg}\end{array}$ \\
\hline B7 & $\begin{array}{l}\text { 5-6 } \text { mcga }^{\text {a }} \\
\text { (breastmilk; } 1 \text { cup } \\
\text { sweet potato) }\end{array}$ & $\begin{array}{l}8-20 \text { mcga (5 oz } \\
\text { salmon; } 2 \text { eggs) }\end{array}$ & $30 \mathrm{mcg}^{\mathrm{a}}$ ( 5 cups almonds) & 30 mcga (3 eggs) $^{2}$ & $35 \mathrm{mcg}^{\mathrm{a}}$ (3.4 oz beef liver) \\
\hline B9 & $\begin{array}{l}65-80 \text { mcg DFE }{ }^{a, b} \\
\text { (breastmilk; } 3 / 4 \text { cup } \\
\text { avocado) }\end{array}$ & $\begin{array}{l}\text { 150-200 mcg DFE } \\
\text { (breakfast cereal; } \\
1 \text { cup white rice) } \\
\text { UL }=300-400 \text { mcg }^{\text {b }} \\
\text { DFE }^{\text {b }}\end{array}$ & $\begin{array}{l}400 \text { mcg DFE }^{\mathrm{b}} \text { ( } 2 \text { cups } \\
\text { black-eyed peas) } \\
\mathrm{UL}=1000 \text { mcg DFE }^{\mathrm{b}}\end{array}$ & $\begin{array}{l}600 \text { mcg DFE }{ }^{\mathrm{b}}(2.3 \\
\text { cups cooked spinach) } \\
\mathrm{UL}=1000 \text { mcg DFE }^{\mathrm{b}}\end{array}$ & $\begin{array}{l}500 \text { mcg DFE }^{\mathrm{b}} \text { ( } 6 \text { oz beef liver) } \\
\mathrm{UL}=1000{\text { mcg } \text { DFE }^{\mathrm{b}}}^{\text {) }}\end{array}$ \\
\hline
\end{tabular}


Toxicity risks

Toxicity with preformed vitamin A; no known risks from excess provitamins. Pseudotumor cerebri, skin irritation, arthralgias, hepatic injury, coma, and death. Congenital birth defects with excess vitamin A/retinoids in pregnancy. Increased mortality with chronic supplementation.

Risk only from excess supplements; no risk with excess sun exposure. Hypercalcemia, nephrocalcinosis, nephrolithiasis, bone demineralization, and cardiovascular calcium deposition.

High-dose supplementation increases hemorrhage risk. Increased mortality with chronic supplementation.

No reported risks associated with vitamin $\mathrm{K}$ in humans/ animals. Vitamin $\mathrm{K}$ antagonizes effect of warfarin.

\section{Notes}

Concomitant use of synthetic retinoids can increase risk of hypervitaminosis $A$.

5-30 min of midday sun exposure to face, arms, and legs twice weekly is sufficient to maintain vitamin D levels.

Large doses with concomitant anticoagulants/ antiplatelets can increase bleeding risk. Antioxidants should be avoided with chemotherapy.

Chronic antibiotic use can lead to deficiency by eliminating vitamin $\mathrm{K}$-producing $\mathrm{Gl}$ bacteria.

\begin{tabular}{|c|c|}
\hline Toxiclty risks & Notes \\
\hline No known toxicity or adverse effects. & $\begin{array}{l}\text { Reports of deficient levels with furosemide. } \\
\text { Fluorouracil use has been linked to cases of } \\
\text { beriberi or Wernicke encephalopathy. }\end{array}$ \\
\hline No known toxicity or adverse effects. & $\begin{array}{l}\text { Conversion of tryptophan to NAD and B6 } \\
\text { to coenzyme pyridoxal } 5^{\prime} \text {-phosphate are } \\
\text { dependent on riboflavin. }\end{array}$ \\
\hline $\begin{array}{l}\text { No risk from niacin in food. High supplement/ } \\
\text { pharmacologic intake: flushing, nausea, paresthesias, } \\
\text { headache, dizziness, hypotension, fatigue, insulin } \\
\text { resistance, macular edema. Chronic high-dose use: } \\
\text { hepatotoxicity. }\end{array}$ & $\begin{array}{l}\text { Isoniazid and pyrazinamide are structural } \\
\text { analogs of niacin and interrupt production } \\
\text { from tryptophan and conversion to NAD. } \\
\text { Large doses can raise blood glucose levels. }\end{array}$ \\
\hline No known toxicity or adverse effects. & \\
\hline $\begin{array}{l}\text { No risk of toxicity from food sources. Chronic high- } \\
\text { dose supplementation: severe/progressive sensory } \\
\text { neuropathy, ataxia, painful/disfiguring dermatologic } \\
\text { lesions, and photosensitivity. }\end{array}$ & $\begin{array}{l}\text { Vitamin B6 supplementation is recommended } \\
\text { with isoniazid use to prevent neuropathy. }\end{array}$ \\
\hline $\begin{array}{l}\text { No evidence of toxicity at high doses. May interfere } \\
\text { with diagnostic testing, specifically thyroid function } \\
\text { tests, pro-BNP, troponins, vitamin D. }\end{array}$ & $\begin{array}{l}\text { Anticonvulsants may increase biotin } \\
\text { catabolism and reduce serum levels. }\end{array}$ \\
\hline $\begin{array}{l}\text { Limited evidence but concern for: accelerated } \\
\text { progression of preneoplastic lesions; immune } \\
\text { dysfunction; cognitive impairment in older adults; } \\
\text { diminished cognitive development of infants. }\end{array}$ & $\begin{array}{l}\text { High intake of folate may precipitate and/ } \\
\text { or mask the symptoms of B12 deficiency. } \\
\text { Methotrexate is a folate antagonist; folate } \\
\text { supplements can interfere with effect. }\end{array}$ \\
\hline
\end{tabular}




\section{TABLE W1}

Vitamin overview: RDA and toxicity risk ${ }^{2}$ (cont'd)

\begin{tabular}{|c|c|c|c|c|c|}
\hline \multicolumn{6}{|c|}{ Water-soluble vitamins } \\
\hline \multirow[t]{2}{*}{ Vitamin } & \multicolumn{5}{|l|}{ RDA } \\
\hline & Infants & Pediatrics & Adults & Pregnancy & Breastfeeding \\
\hline B12 & $\begin{array}{l}0.4-0.5 \mathrm{mcg}^{\mathrm{a}} \\
\text { (breastmilk; } 5 \mathrm{oz} \\
\text { chicken breast) }\end{array}$ & $\begin{array}{l}0.9-1.2 \text { mcg ( } 1 \mathrm{oz} \\
\text { Swiss cheese; } 6 \mathrm{oz} \\
\text { cured ham) }\end{array}$ & $\begin{array}{l}2.4 \text { mcg ( } 3 \text { oz canned } \\
\text { tuna) }\end{array}$ & $\begin{array}{l}2.6 \text { mcg ( } 2 \text { oz cooked } \\
\text { trout) }\end{array}$ & $2.8 \mathrm{mcg}$ (6 oz top sirloin cooked) \\
\hline C & $\begin{array}{l}40-50 \mathrm{mg}^{\mathrm{a}} \\
\text { (breastmilk; } 1 \text { cup } \\
\text { raw cauliflower) }\end{array}$ & $\begin{array}{l}15-45 \mathrm{mg} \text { (1 raw } \\
\text { tomato; } 1 / 2 \text { cup } \\
\text { cooked brussels } \\
\text { sprouts) } \\
\mathrm{UL}=400-650 \mathrm{mg}\end{array}$ & $\begin{array}{l}75-90 \mathrm{mg} \text { (1 orange; } 1 \\
\text { cup strawberries) } \\
\mathrm{UL}=2000 \mathrm{mg}\end{array}$ & $\begin{array}{l}85 \text { mg (1 grapefruit) } \\
U L=2000 \text { mg }\end{array}$ & $\begin{array}{l}120 \mathrm{mg} \text { (1 cup raw green peppers) } \\
\mathrm{UL}=2000 \mathrm{mg}\end{array}$ \\
\hline
\end{tabular}

BNP, B-type natriuretic peptide; DFE, dietary folate equivalents; NAD, nicotinamide adenine dinucleotide; RAE, retinol activity equivalents; RDA, recommended dietary allowance; UL, upper limit.

${ }^{a}$ Adequate intake (AI) - insufficient evidence to establish an RDA.

${ }^{b}$ RDA for vitamin A and folate listed as retinol activity equivalents (RAE) and dietary folate equivalents (DFE) respectively. Vitamers of these vitamins have various levels of activity. 
Toxicity risks

No known toxicity or adverse effects.

Low risk of toxicity. Diarrhea, nausea, abdominal cramps. Inconsistent evidence of risk of kidney stones.

\section{Notes}

Deficiency is treated with injectable B12 to avoid potential absorption barriers. High-dose oral treatment may also be effective. Neurologic changes can occur without anemia and be irreversible.

Vitamin C content in food is reduced by prolonged storage and cooking. Caution with hemochromatosis; can increase iron absorption. Antioxidants should be avoided with chemotherapy. 